\title{
Determining the Different E-Services Required By the Pakistani Citizens
}

\author{
Adnan Mahar ${ }^{1}$, Muhammad Nawaz Tunio ${ }^{2}$, Waseem Ahmed Soomro ${ }^{3}$ \\ ${ }^{1 \& 3}$ (Education and literacy department, Government of Sind, Pakistan) \\ ${ }^{2}$ (Sindh Agriculture University, Tandojam, Pakistan)
}

\begin{abstract}
This primary effort of this research study was to highlight the needs of citizens in Pakistan. Since Pakistan is a developing country and day-per-day the demands and provisions of e-Services are being increased, therefore, this same research can be extended to the study of available e-Services in Pakistan in terms of respective levels of e-Services. This study might come up with the exact data, methods, policies, strengths and major weaknesses of continuous shifting of the e-Services from the bottom to the top level.
\end{abstract}

Keywords: e-service, ICT, transaction, globalization.

\section{Introduction}

Pakistan is a third world country with huge commercialization; e-service is essentially required to facilitate the trade and transactions at local and international level. Citizen of Pakistan need e-service in context of education, job, utility bills, passport and taxation [1](Kayani, et. al., 2011)

Electronic Government Directorate (EGD) was established as a unit within the Ministry of Science and Technology in Pakistan in order to employ different projects correlated to e-government. In June 2005, the National E-Government Council (NEGC) accepted the "E-Government Strategy Five Year Plan," which was designed to offer basic infrastructure to all government agencies, design and develop common applications for all government divisions, provide e-services to citizens, and establish standards for e-government projects [2] (Pak e-government strategy, 2005).

Pakistan needs proper strategy to implement the policy of e-service at the grass root level like other countries. Emerging tools should be incorporated to boost up the e-services in order to offer socio-economic linkages between different societies [3].

According to the UN (2010) annual survey of e-government, in the South Asian region, most portals and websites have remained dormant since 2008 as shown in Table 1 [4].

\begin{tabular}{|l|l|l|l|}
\hline \multirow{2}{*}{ Country } & \multicolumn{3}{c|}{ World e-government ranking } \\
\cline { 2 - 4 } & \multicolumn{1}{|c|}{$\mathbf{2 0 0 5}$} & \multicolumn{1}{c|}{$\mathbf{2 0 0 8}$} & $\mathbf{2 0 1 0}$ \\
\hline Maldives & 77 & 95 & 92 \\
\hline Sri Lanka & 94 & 101 & 111 \\
\hline India & 87 & 113 & 119 \\
\hline Pakistan & 136 & 131 & 146 \\
\hline Bhutan & 130 & 134 & 152 \\
\hline Bangladesh & 162 & 142 & 134 \\
\hline Nepal & 126 & 150 & 153 \\
\hline Afghanistan & 167 & 168 \\
\hline
\end{tabular}

In 2008 and 2010, UN e-government world surveys ranked Pakistan 131st and 146th, respectively.

However, the South Asian region regressed in the 2010 survey and remains far below the world

Average, Pakistan scored 27.55 in the region.

Due to neglecting the people's requirements in global context, s-services are adopted at low level in the developing countries like Pakistan. Here e-services are not completely provided as per need. Government should formulate policy framework for the adoption and application of e-services in the interest of common citizens.

There are few emerging indicators which have developed transformation society in Pakistan, those indicators include e-government, IT policy, rapid growth of the IT and telecom sector, increased teledensity, Internet services, e-learning, e-health, e-commerce, etc [5] (Shafique, 2008).

It is essential to establish Information \& Communication Technology (ICT) and integrate for the social cause in order to increase the acquisition and application of new technology in order to get maximum benefit from the miracle of technology through e-services [6]

E-services in education system can bring our society from developing phase to developed phase through bringing Information \& Communication Technology (ICT) in common use of citizen of Pakistan [7]. 


\section{Objectives}

- To evaluate the types of e-services offered in Pakistan

- To analyze the priorities of people about e-services in Pakistan

E-Education Facility

\section{The Priority-Wise Demanded E-Services By Citizens}

The number of people demanding the boosting up e-Education is amazing. All the respondents have simultaneously demanded that the education must be focused on the priority of provision of e-Services by the government. The demands however, are slightly varied in responses. Some demanded online courses, others demanded the access to universities and yet others demanded the websites for all the educational institutes of country and their regular and timely update.

\section{Registration Of Citizens}

The second priority was given to the online registration of all the citizens at districts and tehsil/taluka level. The same was also integrated with the house old, birth and citizenship information, which comes in the figure 11 at 8 th position of priority.

\section{Online Payment And Deduction Of Taxes}

Respondents repeated the need of payment and deduction of taxes online. They used different options as, online payment of taxes, regular deduction of taxes, online disbursement of salaries etc.

\section{Access To The Higher Government Officials And Authorities}

In this category, respondents demanded the complaint cells of all the government departments, contact to the president of Pakistan, Prime Minister, Chief Justice of Pakistan, Chairman NAB, Ministers and Advisors of Federal and Provincial departments etc.

\section{E-Health Facility}

Respondents also demanded the online appointment of patients with doctors, online OPDs of all the government Hospitals, Online Medical Advices etc.

\section{Online Police Complaint Services}

Respondents also demanded that the record of police cases and their status be regularly updated on the website of each Police of every Province. They also demanded the online FIR Lodging Facility from the government.

\section{Online Training Of Government Employees}

A very high demand was made by the majority of the people that government Employees must be trained properly about the use of ICT and internet services. They demanded the online training courses for employees as well as all the other people of society to benefit the most.

Besides these all, there were the demands of renewal of license, vehicle registration systems, and government employees' personal and official records on the websites of the respective departments, e-Shopping facility and online registration for Hajj pilgrims as well.

At the end, in general suggestions regarding e-Services, a majority of people demanded that Internet facility, quality and proper bandwidth may be improved and extended to every citizen of Pakistan. Places where internet is already available, its speed may be increased and basic training and awareness of internet and ICT be given to all the government Employees of Pakistan.

Table 2 The priority and repetition wise data of the citizens' demands

\begin{tabular}{|r|l|r|}
\hline S. No & Demanded e-Service & $\begin{array}{l}\text { Number of people, who demanded the } \\
\text { service in the survey }\end{array}$ \\
\hline 1. & Online Trainings of government Servants & 92 \\
\hline 3. & Personal and Employment Record of all government Employees & 78 \\
\hline 3. & e-Education Facilities & 148 \\
\hline 4. & Access to higher government Officials and Authorities. & 115 \\
\hline 5. & Online Payment and deduction of Taxes. & 92 \\
\hline 6. & Household, Birth and Citizenship information of all the citizens & 114 \\
\hline 7. & e-Health facilities to citizens & 32 \\
\hline 8. & e-Shopping opportunities & 67 \\
\hline 9. & e-Voting system & 87 \\
\hline 10. & Driving License Renewal & \\
\hline
\end{tabular}




\begin{tabular}{|r|l|r|}
\hline 11. & CNIC Registration of Citizens & 140 \\
\hline 13. & Telephone and Citizen Address Directories & 59 \\
\hline 13. & Vehicle and Land Registration Record & 32 \\
\hline 14. & Police Complaint Services & 112 \\
\hline 15. & Online Research journal & 25 \\
\hline 16. & Online Maps of the Pakistan and its Geographic Locations & 30 \\
\hline 17. & City survey Records & 15 \\
\hline 18. & Online Assistance in Legal Matters & 24 \\
\hline 19. & Online Hajj Registration for Pilgrims & 32 \\
\hline
\end{tabular}

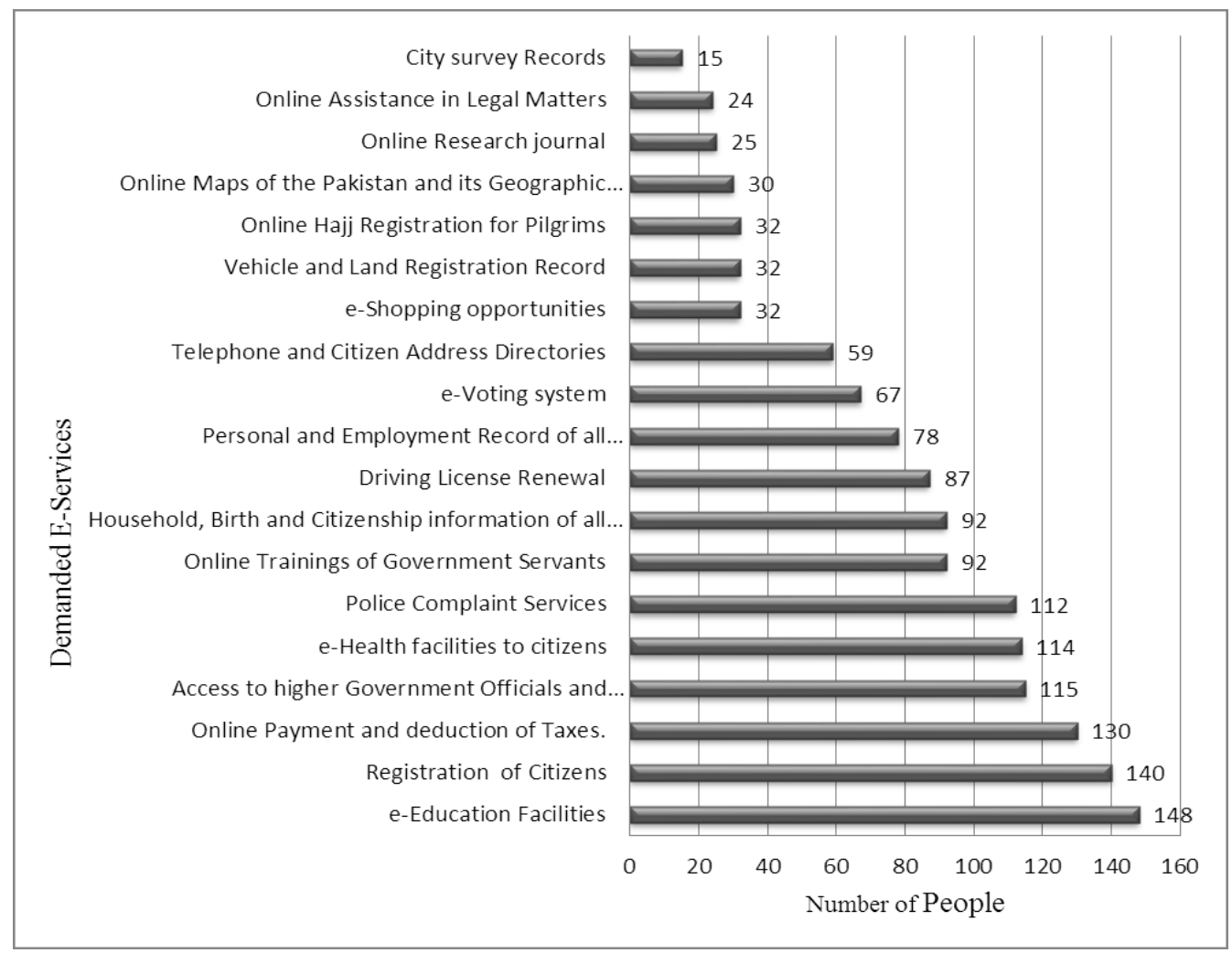

Figure 1 Particular e-Services demanding by the people Source: Survey Results

\section{The Priority-Wise Demanded E-Services By Citizens}

\section{E-Education Facility}

The number of people demanding the boosting up e-Education is amazing. All the respondents have simultaneously demanded that the education must be focused on the priority of provision of e-Services by the government. The demands however, are slightly varied in responses. Some demanded online courses, others demanded the access to universities and yet others demanded the websites for all the educational institutes of country and their regular and timely update.

\section{Registration Of Citizens}

The second priority was given to the online registration of all the citizens at districts and tehsil/taluka level. The same was also integrated with the house old, birth and citizenship information, which comes in the figure 11 at 8th position of priority.

\section{Online Payment And Deduction Of Taxes}

Respondents repeated the need of payment and deduction of taxes online. They used different options as, online payment of taxes, regular deduction of taxes, online disbursement of salaries etc.

XIII. access to the higher government officials and authorities

In this category, respondents demanded the complaint cells of all the government departments, contact to the president of Pakistan, Prime Minister, Chief Justice of Pakistan, Chairman NAB, Ministers and Advisors of Federal and Provincial departments etc. 


\section{E-Health Facility}

Respondents also demanded the online appointment of patients with doctors, online OPDs of all the government Hospitals, Online Medical Advices etc.

\section{Online Police Complaint Services}

Respondents also demanded that the record of police cases and their status be regularly updated on the website of each Police of every Province. They also demanded the online FIR Lodging Facility from the government.

\section{Online Training Of Government Employees}

A very high demand was made by the majority of the people that government Employees must be trained properly about the use of ICT and internet services. They demanded the online training courses for employees as well as all the other people of society to benefit the most.

Besides these all, there were the demands of renewal of license, vehicle registration systems, government employees' personal and official records on the websites of the respective departments, e-Shopping facility and online registration for Hajj pilgrims as well.

At the end, in general suggestions regarding e-Services, a majority of people demanded that Internet facility, quality and proper bandwidth may be improved and extended to every citizen of Pakistan. Places where internet is already available, its speed may be increased and basic training and awareness of internet and ICT be given to all the government Employees of Pakistan.

\section{Conclusion:}

Pakistan is one of those developing countries of the world, who are quite new to the e-Government. It therefore, demands a good deal of effective strategic steps towards better provision of e-Services to citizens as their needs of e-Services are being increased. A good majority of people visits the Websites of Federal and Provincial Public Service Commissions. A good positive shift has been made, (when this thesis was being composed) the official website of Federal Public Service Commission (FPSC), i.e. www.fpsc.gov.pk had crossed the informational level and had now jumped into interactional and transactional level of e-Service delivery, as now the citizens could not only see the information regarding any job on this site, but also apply for the same online. This is therefore a positive sign that our departments are not only going step ahead but the citizen satisfaction is also being earned.

\section{Acknowledgements}

Authors are cordially thankful to the Dr. Qazi Muhammad Moinudin Abro, Associate Professor MUISTD, for his technical guide and participants who hardly managed to give time from their busy schedule for this research.

\section{References:}

[1] Kayani, M. B., Ehsan ul Haq, Perwez, M. R., Humayun, H. Analyzing Barriers in e-Government Implementation in Pakistan. International Journal for Infonomics (IJI), Volume 4, Issue 3/4. 2011.

[2] Pak e-government strategy. 'E-Government Strategy and 5-Year Plan for the Federal Government'. 2005. Retrieved by ttp://202.83.164.29/egdsite05/downloads/EGovernment\%20Strategy\%20and\%205-Year\%20Plan\%20(19[1].06.2005).pdf>. [Accessed 17/06/2013].

[3] Ahmad, M. O., Markkula, J., Oivo, M. Factors influencing the adoption of e-government services in Pakistan. European, Mediterranean \& Middle Eastern Conference on Information Systems 2012 (EMCIS2012) June 7-8, Munich, Germany. 2012.

[4] UN. 'United Nation E-Government survey', Retrieved by <http://unpan1.un.org/ intradoc/ groups/public/documents/UN-DPADM/ UNPAN038853.pdf >, [Accessed 15.06.2013]. 2010.

[5] Shafique, F. Indicators of the Emerging Information Society in Pakistan. Information Development. vol. 24 no. 1 66-78. 2008

[6] Tunio, M. N., Rashdi, P. I. S., Muhammad, Q., Abro, M., Sartaj, S., \& Tunio, S. P. Social Impact of Virtual Communication on Nascent Society of Pakistan. IOSR Journal Of Humanities And Social Science (IOSR-JHSS) Volume 10, Issue 5, 2013, PP 68-74. eISSN: 2279-0837, p-ISSN: 2279-0845. www.Iosrjournals.Org

[7] Tunio, M. N., Arain, N. R., \& Tunio, S. P. Assessment of Computer Literacy at Secondary Education Level in Rural Areas of Sindh (Pakistan). International Journal of Emerging Science and Engineering (IJESE) ISSN: 2319-6378, Volume-1, Issue-7, 2013 